\title{
Consuming Animal Creatures: The Christian Ethics of Eating Animals
}

\section{David L. Clough}

\begin{abstract}
This article argues that Christians have strong faith-based reasons to avoid consuming animal products derived from animals that have not been allowed to flourish as fellow creatures of God, and that Christians should avoid participating in systems that disallow such flourishing. It considers and refutes objections to addressing this as an issue of Christian ethics, before drawing on a developed theological understanding of animal life in to argue that the flourishing of fellow animal creatures is of ethical concern for Christians. Since the vast majority of animal products currently available for purchase are derived from farmed animals reared in modern intensive modes that fail to allow for their flourishing, and this practice is harmful for humans and the environment as well as farmed animals, the article argues that Christians should avoid consuming these products.
\end{abstract}

\section{Keywords}

Christian, theology, ethics, animals, food, eating, farming

\section{Text}

In this article, I will argue that Christians have strong faith-based reasons to avoid consuming animal products derived from animals that have not been allowed to flourish as fellow creatures of God, and that Christians should avoid participating in systems that disallow such flourishing. I propose this as an argument for a moderate position. I think there are good arguments for Christian vegetarianism and veganism, but also reasonable arguments against, so that Christians can legitimately disagree about whether such dietary restrictions are faith-based obligations. Christians legitimately disagree about whether pacifism is a faith-based obligation in a similar way. The 
position for which I want to argue here, however, is more moderate and I think should gain the consent of all Christians: that if we are to make use of animals for food, we should ensure that such use respects their relationship to us as fellow creatures of God. While the position is moderate, its practical implementation would be radical. If we also agree that the vast majority of meat, dairy, and eggs are currently produced in ways that fail to respect the animals as fellow creatures of God — for which I will present a summary argument, which I think is uncontroversial — then we will reach the conclusion that the vast majority of animal products currently offered for sale should be off the table for Christians. If I am right that this position is a plausible interpretation of Christian ethics in this area, it is striking that this issue of daily Christian practice has not received greater attention from Christian ethicists. ${ }^{1}$

${ }^{1}$ This is not to say that it has not been noticed before, of course. Rachel Carson's pioneering 1961 work Silent Spring exposing the cruelties of modern intensive farming was informed by her Christian faith (Rachel Carson, Silent Spring (Boston: Houghton Mifflin, 1961); see Lisa H. Sideris, 'The Secular and Religious Sources of Rachel Carson's Sense of Wonder', in Rachel Carson: Legacy and Challenge, Lisa H. Sideris, and Kathleen Dean Moore (eds.), (New York: SUNY Press, 2008), pp. 232-50), Andrew Linzey has addressed closely related issues in a number of works (e.g. Andrew Linzey, Animal Theology (London: SCM Press, 1994)), and Michael Northcott has noted the impacts of intensive farming on farmed animals (e.g. Michael S. Northcott, The Environment and Christian Ethics (Cambridge: Cambridge University Press, 1996), p. 294). Other books on Christian food ethics, referenced later in this article, also treat the topic. It remains the case, however, that the ethics of the Christian consumption of intensively farmed animal products has not been widely discussed. 


\section{Objections to a Christian food ethic treating the consumption of animals}

We are rightly sceptical about ethical arguments for radical positions, so before presenting arguments in favour of my position, let me consider three potentially fatal points that would quickly defeat the argument I am seeking to develop.

First, it seems unlikely that the vast majority of Christians today and in past generations could be in error in failing to recognise that their faith required abstention from most animal products. There is a strong and plausible argument from conservatism that should make us pause before accepting this judgement, and a parallel requirement on anyone advancing such a claim to provide an error theory explaining how things could have come to such a pass. My explanation for this is that the ways in which farmed animals are raised has changed radically and Christians, together with others, have been inattentive to these changes. I was shocked when I first came across the claim, not so long ago, that the first large-scale rearing of farmed animals exclusively for meat was in England in the late eighteenth century: up to that point meat was largely a by-product of keeping animals for other reasons, such as milk, eggs, and wool. Meat was a cash-crop made possible by the Highland clearances in Scotland and the enclosures in England, displacing the largely arable agriculture of the poor, and, as Percy Bysshe Shelley noted in 1813, causing wastage of food productivity 'absolutely incapable of calculation'. ${ }^{2}$ The intensification of farmed animal production has developed over the past two hundred years since, but accelerated rapidly from the mid-twentieth century. Most farmed animals are now raised in ways that would be unrecognisable in comparison to conditions only a few decades ago. Broiler hens are a particular extreme example: bred through intricate multi-generational programmes to reach slaughter weight at only 35 days old, their young legs unfit to support their unwieldy bodies, living the entirety of their lives in warehouses with

${ }^{2}$ Tristram Stuart, The Bloodless Revolution: A Cultural History of Vegetarianism From 1600 to Modern Times (New York; London: W. W. Norton and Co., 2006), 403; Shelley's A Vindication of Natural Diet quoted by Stuart, pp. 405-6. 
artificial night and day, automated feeding and climate control, with human interaction restricted to a daily patrol to remove the dead, and finally stuffing them into crates for transport to slaughter. I still remember the experience of holding a straggly 16 day old hen in the midst of a huge broiler shed, surrounded by 26,000 of her fellows, with 23 similar sheds nearby, filled with the 600,000 birds that had been delivered together as day-old chicks two weeks previously. I had the strong sense that these animals were not being treated as animals, but as a crop, grown for harvest. The hen I held had only just lost her fluffy yellow chick feathers, yet was nearly halfway through her life. Pigs fare little better: most are also raised indoors in crowded conditions where farmers often resort to cutting off their tails to reduce the injuries from aggression and boredom that such intelligent and socially complex animals experience in such a monotonous environment.

My point is that most of what now generates the need for radical changes in the Christian ethics of consuming animals is radical changes in farmed animal practice — changes which the farming industry has understandably not been active in publicizing to consumers, and of which most consumers have therefore been unaware. Therefore, the act of eating chicken today is different ethically from the act of our grandparents eating chicken, which they did much less frequently because before the invention of broiler hens chicken was a luxury compared with cheaper alternatives such as beef. ${ }^{3}$ My position does not imply a retrospective judgement that our grandparents were wrong in eating farmed animals, but that the nature of the industry now is that we almost always are. It is also helpful to note that my position is also not a retrospective judgement in relation to what Jesus ate, which is commonly raised in discussions of Christian vegetarianism. Animals were not raised intensively in first century Palestine, so my argument that intensively raised farmed animals should be off the table for Christians do not apply to Jesus's

${ }^{3}$ A Godley, and B Williams, Democratizing Luxury and the Contentious "Invention of the Technological Chicken” in Britain, Business History Review (Reading, UK: Centre for Institutional Performance, University of Reading, 2009), p. 1. 
dietary choices. In summary, I am arguing that the primary reason most Christians have not recognised the ethical problems associated with eating animal products is that farmed animal practice has changed comparatively recently and we have failed to attend to and appreciate the ethical implications of this change.

A second potential way of defeating my argument that Christians should not consume products derived from farmed animals that have not been allowed to flourish as fellow creatures of God begins from New Testament teaching. 'Do you not see that whatever goes into a person from outside cannot defile, since it enters not the heart but the stomach, and goes out into the sewer?' (Mk 7.18-19) These scatological words of Jesus recorded by Mark and echoed by Matthew (Mt. 15.11, 16) seem to short-circuit any Christian food ethics, especially as Mark adds the parenthesis that in saying this Jesus declared all foods clean. Other New Testament passages echo this licence to eat freely: Jesus allows his disciples to pluck heads of grain on the Sabbath and eat them (Mk 2.23-4 \& par.); Paul states that only those weak in conscience are concerned about eating meat offered to idols, and states that eating or not eating is irrelevant to our relationship to God (1 Cor. 8.4-8; cf. Rom. 14.2); and Peter receives a shocking vision in which he is told to kill and eat all kinds of animals, because God has made them all clean (Acts 10.9-16). Clearly, the very particular context of early Christian communities negotiating their relationship with Jewish food practices is a crucial background here, and it is inappropriate to determine Christian food ethics entirely within this context, but the texts do not encourage Christian attention to the ethics of eating. Given this early history, it is surprising that Christian monastic movements so often made stringent dietary demands of their members, and that traditions of fasting became so widespread, but the Reformation questioned this practice, with Luther reemphasising Paul's position that neither eating nor fasting counts for anything, ${ }^{4}$ and much more recently in 1966 Roman Catholic fasting

\footnotetext{
${ }^{4}$ See, for example, Luther's commentary on Gal. 6.15 in Lectures on Galations (Martin Luther,
} 
requirements were relaxed. ${ }^{5}$ All this seems an unpromising context for Christian attention to the ethics of what we eat.

Yet what we eat is of very clear and direct relevance for Christian ethics, as captured memorably in the title of Ron Sider's 1978 book Rich Christians in an Age of Hunger. ${ }^{6}$ What we consume, including what we take in through our mouths, has obvious and problematic impacts on other humans, on non-human animals, and on the wider environment. To take one example: we currently devote $78 \%$ of all agricultural land to raising farmed animals, and feed more than one third of global cereal output to those animals. ${ }^{7}$ Philosophers and theologians from Plato onwards have noted that raising animals for meat is an inefficient use of land, and it is abundantly clear that fewer people would go hungry and thirsty if the land were used to grow crops instead, where this is possible. ${ }^{8}$ We may disagree about the ethical implications of this observation, but we cannot reasonably use the biblical passages cited above to deny its relevance for Christian ethics. As the growing literature in this area confirms, twenty-first century Christian ethics cannot therefore afford

Luther's Works, eds. Helmut T. Lehmann, and Jaroslav Pelikan (Philadelphia: Muhlenberg Press, 1958), vol. 27, p. 138).

${ }^{5}$ In Pope Paul VI's Apostolic Constitution Paenitemini he allowed local bishops to replace Friday fasts from meat with other forms of penance (Pope Paul VI, Paenitemini: On Fast and Abstinence (Rome: Vatican, 1966), ch. III).

${ }^{6}$ Ronald J. Sider, Rich Christians in an Age of Hunger: Twentieth Anniversary Edition (London: Hodder \& Stoughton, 1997).

${ }^{7}$ David Clough, On Animals: Vol. II. Theological Ethics (London: T \& T Clark/Bloomsbury, forthcoming 2017), ch. 2.

${ }^{8}$ Stuart, Bloodless Revolution, 402, citing Plato's Republic, 373d; Clough, On Animals II, ch. 2. 
to leave food ethics beyond its range of concerns. ${ }^{9}$ There is nothing wrong in eating an apple as such, but if food is scarce and eating it would be to take more than our share, then the decision to take and eat it is obviously an ethical one. Similarly, if the apple has been produced under conditions that fail to provide adequately for agricultural workers, or using pesticides that poison sources of water, or do other unwarranted damage to other animals or the environment, this wider context makes the decision to purchase and consume it relevant to ethics. In a Christian context what we eat is an ethical question because of the implications of our consumption for fellow creatures of God. This is the basis for a Christian ethics of food.

In this paper, I want to focus on a particular part of this issue: the ethics of consuming animal products. Here we encounter a third possible defeater to the argument I announced. You may agree that Christian food ethics should properly take account of the implications of our consumption for our human neighbours, but deny that we should be concerned about the impacts on other animals. There are good theological foundations for such a lack of concern for animals. In Augustine's discussion of the Decalogue prohibition of murder in The City of God, he notes that some people have said that the prohibition of killing should be extended to beasts and cattle, but that this would lead to a reductio ad absurdam because if it is unlawful to kill animals, why not plants as well? To avoid involving 'ourselves in the foul error of the Manichees', Augustine draws on the Greek idea of the soul as threefold: plants have a nutritive soul, animals have a sensitive soul in addition, but humans uniquely have a rational soul. 'Thou shalt not kill' does not refer to plants because they are

${ }^{9}$ See, for example, Stephen H. Webb, Good Eating, The Christian Practice of Everyday Life (Grand Rapids, MI: Brazos Press, 2001); Rachel Muers, and David Grumett (eds.), Eating and Believing: Interdisciplinary Perspectives on Vegetarianism and Theology (London: T \& T Clark, 2008); L. Shannon Jung, Food for Life: The Spirituality and Ethics of Eating (Minneapolis: Fortress Press, 2004); Norman Wirzba, Food and Faith: A Theology of Eating (Cambridge: Cambridge University Press, 2011). 
not sensitive, and does not refer to animals because they have no society with us in reason, he argues, and because God has ordained that their deaths and lives may justly serve our use. ${ }^{10}$ When Aquinas considers whether it is permissible to kill any living thing in the the Summa theologica, he cites Augustine's argument about animals being irrational, and adds Aristotle's view in the the Politics that plants were created for the sake of animals and animals for the sake of human beings. ${ }^{11}$ Aquinas draws on Aristotle to argue that, just as some human races are 'intended by nature for slavery' so that it is just to go to war to enslave them, so we can see animals as naturally enslaved for the use of others. ${ }^{12}$ Elsewhere in the Summa, Aquinas argues that animals are excluded from consideration in relation to both justice and charity. ${ }^{13}$

Let us agree to agree with Augustine and Aquinas that the Decalogue does not prohibit killing animals, and agree to disagree absolutely with Aristotle and Aquinas in their view that there are humans who are naturally ordered to be slaves to others. What should we make of the argumentation between these two points? First, while Augustine is right that killing animals is not

${ }^{10}$ Saint Augustine, The City of God, ed. R. V. G. Tasker, trans. John Healey (London: Dent \& Sons, 1945), I.19.

${ }^{11}$ Thomas Aquinas, Summa Theologica, trans. Fathers of the English Dominican Province, (London: Blackfriars, 1963), II-II, 64.1, citing Aristotle, Politics, trans. Reeve, C. D. C. (Indianapolis: Hackett, 1998), I.8, 1256b.

${ }^{12}$ Aquinas, Summa Theologica, II-II, 64.1.

${ }^{13}$ Aquinas, Summa Theologica, 1.2, qu. 102, a. 6; Aquinas, Summa Theologica\}, 2.2, qu. 25, a. 3. It is important to note that there are other much more positive dimensions of Aquinas's thought for engaging theologically with animals. For discussion of these, see Judith A Barad, Aquinas on the Nature and Treatment of Animals (San Francisco; London: International Scholars, 1995) and John Berkman, 'Towards a Thomistic Theology of Animality', in Creaturely Theology: On God, Humans and Other Animals, Celia Deane-Drummond, and David Clough (eds.), (London: SCM, 2009). 
prohibited here, he is wrong that we have no way of recognizing the difference between killing animals and plants. As we shall see below, Christians have biblical and theological grounds for recognizing animal creatures as different from plants, and these differences have implications for how we treat them. Our rejection of Aquinas's analogy from races naturally destined to be slaves ought to lead us to question the analogous Aristotelian logic that plants were created for animals and animals for humans. Genesis 1, notably, provides no basis for such a claim: the creatures of each day are declared good in themselves without reference to their utility to any other creatures. ${ }^{14}$ Genesis 1 gives humans dominion over other animals, but its specification of plants as food both for animals and humans, suggests that this dominion does not include the taking of their lives, and the peaceable coexistence of humans with the animals in Genesis 2 strengthens the case for a dominion that does not involve killing. After the fateful events of Genesis 3, and after the flood God causes in eventual response, God gives permission for the first time for humans to eat other animals provided they do not consume their life blood (Gen. 9.3-4), but we might well follow Luther and many other theologians in interpreting this as a departure from the ideal of Genesis 1, especially in the light of prophetic visions of an end to animal sacrifice and the Messianic reign bringing peace between humans and animals, and Paul's anticipation of the whole creation freed from its groaning bondage. ${ }^{15}$ We should also question Augustine's use of the criterion of reason to identify creatures we may and may not kill: there are human beings not capable of reason whom we rightly wish to protect, and we need to recognise that the abundant examples of animal reasoning offered in contemporary animal studies — such as the politicking of chimpanzees, the abstract logic of parrots, the innovative tool-fashioning of crows, and the ability of dolphins to parse grammar, to take a few of myriad possible examples - mean the Greek idea of a binary divide between humans

${ }^{14}$ Gen. 1.4a, 10b, 12b, 18b, 21b, $25 \mathrm{~b}$.

${ }^{15}$ Martin Luther, Lectures on Genesis, Chapters 1-5, Luther's Works, vol. I, ed. Jaroslav Pelikan (Saint Louis: Concordia, 1958), 36; Isa. 1.11; 66.3; 11.6-9; 65.25-6; Rom. 8.19-22. 
and other animals on the basis of rationality is unsustainable. ${ }^{16}$ The early 14th century English commentary on the Ten Commandments, Dives and Pauper, seems preferable to Augustine and Aquinas's discussions at this point. It notes that Genesis 9 must mean animals are excluded from the Decalogue prohibition on killing, but interprets not consuming animals with their blood as prohibiting cruelty, 'For God that made all has care of all, and he shall take vengeance on all that misuse his creatures. ${ }^{17}$ Karl Barth, influenced by Albert Schweitzer's vision of reverence for all life, recognised the serious ethical attention Christians need to give to fellow animal creatures, stating that animals belong to God, not to human beings, and that therefore any human treatment of other animals must be 'careful, considerate, friendly and above all understanding'. ${ }^{18}$ While Barth considers that this could include killing other animals for food, he judges that such killing could only be obedience to God where it is done under the pressure of necessity. Otherwise, Barth comments strikingly, such killing is nothing less than murder. ${ }^{19}$ Augustine, Aquinas, the author of Dives and Pauper, and Barth are right to recognie that Genesis 9 is a strong argument against the idea that vegetarianism is a universal requirement for Christians, but their positions do not indicate that animals are of no moral account, and we are clearly not necessarily guilty of the 'foul error of

${ }^{16}$ David Clough, On Animals: Vol. I. Systematic Theology (London: T \& T Clark/Continuum, 2012), pp. 30, 69-70.

${ }^{17}$ Priscilla Heath Barnum (ed.), Dives and Pauper (Oxford: Early English Text Society/Oxford University Press, 1976), p. 35 (my rendition in modern English).

${ }^{18}$ Karl Barth, Church Dogmatics, vol. III/4, ed. G. W. Bromiley and T. F. Torrance, trans. A. T. MacKay et al. (Edinburgh: T \& T Clark, 1961), p. 352.

${ }^{19}$ Barth, Church Dogmatics, III/4, pp. 354-5. As noted above, I am not arguing in this paper for Christian vegetarianism or veganism, but Barth's argument here seems to be the most promising starting point for such an argument, given that for most humans today, killing animals is not necessary to gain adequate nutrition. 
the Manichees' in considering that Christians might have faith-based reasons to be concerned about their treatment of animals.

My judgement, then, is that there are no convincing fundamental objections to a Christian ethics of food, nor to thinking Christianly about the ethics of eating animals in particular. I will return to some more specific objections to my argument below, but in the next section I proceed with my positive argument for the position that Christians have strong faith-based reasons to avoid consuming animal products derived from animals that have not been allowed to flourish as fellow creatures of God.

\section{Why the flourishing of farmed animals is a Christian concern}

My project in On Animals Volume I was to set out where animals belong under the major Christian doctrines of creation, reconciliation, and redemption, and this is the foundation of my ethical argument for how Christians should think about the ethics of our relationships with animals. Here is a one-paragraph summary of the argument of the book:

Part I argued that creation is best understood as God's gracious bestowal of being on all creatures, both for their own sake and so that they may glorify God in their participation in the triune life. All creatures are declared good by their creator in their own right; all creatures exist in utter dependence on God and mutual dependence on one another; no creature can be comprehended merely as the means to the flourishing of another. God's animal creatures have particular attributes in common: they are fleshy creatures with the breath of life, especially dependent on other organisms for their survival, often the common subjects of God's blessing and judgement, capable of response to God in a 
distinctive mode. Differences between animal creatures need to be understood in the context of this commonality, with attention given to the particular mode of life of each animal creature, and similarities between groups of animals - such as vertebrates, mammals, or primates - not neglected in the task of specifying the particularity of the human mode of being an animal creature. Part II treated the doctrine of reconciliation, arguing that God's other animal creatures cannot be neglected in accounts of the incarnation or atonement. Instead, Christians celebrate the New Testament confession of a God who took on creaturely flesh in order to reconcile all things in heaven and on earth, and we should understand not only human beings, but all creation, to be the recipients of God's grace in Jesus Christ. Part III argued that what God has created and reconciled, God has reason to redeem, exploring the majestic Pauline vision of the whole of creation liberated from its bondage, and the new patterns of peaceable creaturely living this new creation might require..$^{20}$

Readers unconvinced about these doctrinal claims can examine the arguments I develop for them in On Animals Volume I.

On this basis, we see that a Christian way of understanding the other animals we find that we live among is to recognise them as fellow animal creatures of the God we share, fellow recipients with us of God's grace in creation, reconciliation, and redemption, willed by God to flourish and to glorify God in their flourishing. The great creation Psalm 104 is a magnificent expression of God's rejoicing in the life of every creature, and other psalms celebrate the praise all creatures offer back to God (e.g. Ps. 66.1-4; Ps. 98.7-8), but we find the same theme in Jesus' teaching that not a single sparrow is forgotten by God (Mt. 10.29; Lk. 12.6). Such a Christian vision of the place of animal life in God's ways with the world has clear ethical implications. For Christians, fellow animal

\footnotetext{
${ }^{20}$ Clough, On Animals II, ch. 1.
} 
creatures find their true meaning, like us and all other creatures, in their place in the divine life. Of course, in advance of the inbreaking Messianic reign, our relationships with them are broken and conflictual. We fear the snake and the wolf when they threaten us; we must prevent the rabbit and deer from destroying our crops in order that we may eat. But while we cannot escape our participation with other creatures in the groaning of this present age, and will never through our efforts be able to achieve an Edenic harmony with them, a Christian appreciation of animal creatures means we must nonetheless take care to walk among God's other animal creatures in awareness of their status as our fellows, seek to promote their flourishing when we can, and obstruct it only when we must.

One can imagine any number of religious or irreligious views of the world that justified a wholly anthropocentric ethic in which the entirety of the non-human universe was seen as mere material for the realization of human ends, available for exploitation without any restraint beyond that of what would most efficiently provide for human needs. Looking around us, we might well judge that, with some notable exceptions, our practice in relation to farmed animals is an embodied realization of such an ethic. This is not, however, a Christian way of construing our relationships with others of God's creatures. Christians worship a God who is creator of all creatures, gracious in providing for all creatures, who acted in Jesus Christ to reconcile all things in heaven and earth, as the opening of the letters to the Colossians and Ephesians remind us, and who will free creation from its bondage to enjoy the freedom of the children of God. Once we have seen all creation in this theological framework, we cannot avoid the recognition that in relation to the creatures most like us, our fellow animal creatures, who share with us a radical dependence on God and other creatures to provide the nutrients we need, and who share much of our vulnerability and fragility, we must act carefully and responsibly.

Such an attitude towards animals is deeply-rooted in Christian texts and traditions. Pope Francis's encyclical Laudato Si reminded us of the Franciscan vision in which the other creatures of 
God are our sisters and brothers and 'Every creature is thus the object of the Father's tenderness, who gives it its place in the world. Even the fleeting life of the least of beings is the object of his love, and in its few seconds of existence, God enfolds it with his affection. ${ }^{21}$ Helen Waddell's wonderful anthology Beasts and Saints collects a wide range of stories about the place of animals in the lives of the saints, including my favourite, told of St Macarius of Alexandria, an Egyptian hermit in the 4th century. The story goes that one day as Macarius was sitting in his cell he heard a knocking at his door. Thinking a fellow monk had come to see him, he opened the door and was astonished to find that a hyena had been knocking on the door with her head. She held her puppy in her mouth, and offered the puppy to him, weeping. Macarius took the puppy in his hands and looked to see what was the matter. He saw that the puppy was blind in both eyes. He took the puppy, groaned, spat on the puppy's face and signed it on the eyes with his finger. Immediately, the puppy could see, ran to his mother, suckled from her, and followed her away. The next day the hyena returned and knocked on the hermit's door again. This time when he opened it he saw she had a sheepskin in her mouth. He asked her where she had got the sheepskin, if she had not eaten a sheep, and told her that he would not take the sheepskin if it had come of violence. The hyena struck her head on the ground, bent her paws, and prayed on her knees for him to take it. He said he would not take it unless she promised not to harm the poor by eating their sheep, and she nodded her head as if she were promising him. Then he told her he would not take it unless she promised not to kill another creature, and said if she was hungry she should come to him and he would give her bread. The hyena bent, nodded, and looked him in the eye as if she were promising him. So Macarius offered praises to God for giving understanding to the animals and letting Macarius come to understand God's ways. He took the sheepskin from the hyena and she went away. From time to time she would come to Macarius for food, and he would give her bread. He slept on the sheepskin

${ }^{21}$ Pope Francis, Laudato Si: On Care for Our Common Home (Vatican City State: Vatican Press, 2015), $\S \S 11,77$. 
until he died. ${ }^{22}$ This story of St Macarius combines the recognition that it belongs to Christian holiness to be friendly towards animals, a high view of the capacities of animals to be responsive subjects, and an appreciation that God's will is for peace between all creatures. Together with many other examples from Waddell's collection, such as St Jerome's hospitality to the lion, or St Godric's protection of a stag from the Durham Prince Bishop's hunt, it shows that Christians have long recognised that Christian holiness has implications well beyond the human realm. ${ }^{23}$ Richard Bauckham's discussion of Mark's observation that Jesus was with the wild beasts in the wilderness is of a piece with these stories of saints. ${ }^{24}$

To avoid any misunderstanding, let us be clear that a Christian vision of the meaning of the lives of fellow animal creatures before God does not imply any flat equivalence between humans and other animals. In striking contrast to Peter Singer's slogan that 'all animals are equal', ${ }^{25}$ it is notable that New Testament teaching on God's care of sparrows and obligations to pull sheep out of wells uses the animal examples to show how much more God must care for humans. ${ }^{26}$ We are first called to love our human neighbours. But in very many cases, including the ethics of the intensive farming of animals, we are not forced to choose between similar interests of human and non-human animals. Perhaps there are scenarios where we could recognise Christian arguments for protecting animals even at the cost of human life. Perhaps if one were forced to choose between saving one's

${ }^{22}$ Helen Waddell, Beasts and Saints (London: Darton, Longman \& Todd, 1995), pp. 13-15.

${ }^{23}$ Waddell, Beasts and Saints, pp. 30-38, 90-91.

${ }^{24}$ Richard Bauckham, 'Jesus and the Wild Animals (Mark 1:13): A Christological Image for an Ecological Age', in Jesus of Nazareth: Lord and Christ (Essays on the Historical Jesus and New Testament Christology), Joel B. Green, and Max Turner (eds.), (Grand Rapids: Eerdmans, 1994), pp. 3-21.

${ }^{25}$ Peter Singer, 'All Animals Are Equal', Philosophical Exchange Vol. 1 (1974).

${ }^{26}$ Mt. 10.31; Lk. 12.7; Mt. 12.11-12. 
own life and the life of a beloved companion dog, it could be an act of Christian sacrifice to save the dog. But most of the time we are not forced to choose between human and non-human animal wellbeing in this way, and certainly the moderate position for which I am arguing for here does not require it.

I am proposing, therefore, that a Christian understanding of the meaning of the lives of animal creatures before God means that we should follow God, the Psalmist, and sisters and brothers in faith who have gone before us in delighting in the flourishing of fellow animal creatures, and that this Christian way of seeing animals has implications for ethics. I suggest that Christians have faithbased reasons to avoid obstructing the flourishing of other creatures where possible, and, where possible, to promote their flourishing. This is a modest claim, recognizing, as noted above that there are many instances of conflict where we can only flourish ourselves by blocking the flourishing of other animals, and many other cases where we are powerless to help them. It could usefully be made more exact and particular. But even in this broad form, it has clear implications. Needless cruelty is clearly unchristian, such as children tormenting cats or plucking the wings from flies. When I find a spider in my bath, it belongs to my faith to take steps to relocate her, rather than wash her down the plug hole. Perhaps this seems petty or trite, but what else could Pope Francis's reminder about God's love for the most fleeting of life of the least of beings mean for our practice? If I see a dog wounded at the side of the road, it is a Christian response, if possible, to take him to a place where he can be cared for. Interestingly in relation some other accounts of animal ethics, the Christian obligation not to pluck the wings from a fly or wash a spider down the drain does not depend on any prior judgement about the capacities of the creature concerned, but simply our recognition of them as fellow animal creatures of our God.

Let us take another example with relevance to the topic of this paper: the ethics of consuming animals. Currently, virtually all commercial egg production globally involves the sexing of chicks after they hatch, and then the culling of all male chicks, because they are obviously useless for egg 
production, and because they do not belong to the specialist strains bred for broiler sheds, they are also useless for meat. In the UK, most chicks are killed by maceration: being fed into a mincing machine. This is judged by animal welfare researchers to be one of the most humane methods for this culling available. ${ }^{27}$ Globally, over 4 billion chicks are culled after hatching each year. ${ }^{28} \mathrm{I}$ contend that a system that so callously discards the lives of all male chicks in this way is clearly contrary to a Christian obligation not to obstruct the flourishing of fellow animal creatures. The system brings the chicks into being and then prevents their flourishing in the most absolute way possible. Jesus' teaching about sparrows, noted above must mean that not one of these billions of chicks is forgotten by God. The only justification that can be offered for the system is that it enables eggs to be produced and sold more cheaply than would otherwise be possible. The systematic culling is clearly not necessary as such, but is necessary only to produce eggs at a particular price point. If we reverted instead to the systems that obtained previously with breeds of chicken that were used for eggs and meat, the male chicks would be allowed to grow to maturity before slaughter. Here we have conflict between human and non-human interests of a sort: the older system was a less convenient method of obtaining eggs and meant consumers had to pay more for eggs. Providing there are alternative sources of nutrition, however, this is clearly not a life versus life conflict, and I suggest that a Christian appreciation of the day old chicks as fellow animal creatures of God makes clear that their systematic culling is an unacceptable cost of more efficient production methods. This means that virtually all commercially produced eggs, included free-range

${ }^{27}$ S. Aerts, R. Boonen, V. Bruggeman, J. De Tavernier, and E. Decuypere, 'Culling of Day-Old Chicks: Opening the Debates of Moria?', in Ethical Futures: Bioscience and Food Horizons, K. Millar, P. Hobson West, and B. Nerlich (eds.), (Wageningen: Wageningen Academic Publishers, 2009).

${ }^{28}$ Aerts, Boonen, Bruggeman, De Tavernier, and Decuypere, 'Culling of Day-Old Chicks: Opening the Debates of Moria?', p. 117. 
and organic eggs, are produced in ways contrary to a Christian understanding of our responsibilities towards other animals. ${ }^{29}$ This is another example of the difference between Christian and other approaches to animal ethics: for a utilitarian approach, the killing of male chicks is morally irrelevant, provided no significant suffering is involved; for the leading animal rights theory of Tom Regan, the chicks fall well below his threshold for the possession of rights. ${ }^{30}$ To understand the wrongness of killing all male chicks on hatching, we need a moral account that is teleological: able to give an account of what the lives of these chicks are for, as Christian theology can.

If we agree that the 35 day life of a broiler hen referred to above also prevents their adequate flourishing as fellow creatures, then most chicken is also off the menu for Christians. Poultry are by far the most numerous farmed animal, excluding fish: of the 77 billion animals killed for food in

${ }^{29}$ The cages in which the vast majority of the hens not culled are confined globally and which equally clearly prevent their flourishing are an additional reason to avoid eggs from those sources. There has been recent progress in the development of technology to sex chicks before hatching, allowing eggs containing male chicks to be destroyed earlier in their development (Maryn McKenna, 'By 2020, Male Chicks May Avoid Death By Grinder', National Geographic, 2016). This represents a substantial improvement in reducing the distress suffered by male chicks, but destroying life at an earlier stage of development does not eliminate theological concerns about the production process.

${ }^{30}$ Peter Singer notes that it is complicated to give an account of the wrongness of killing in a utilitarian context (Peter Singer, Animal Liberation (London: Pimlico, 2nd ed. 1995), p. 17); Tom Regan suggests 'mentally normal mammals of a year or more' is an appropriate place to securely identify subjects-of-a-life and therefore rights-holders; though he is open to the possibility that birds and fish may also qualify (Tom Regan, The Case for Animal Rights (Berkeley: University of California Press, 2nd ed. 2004), p. xvi). 
2013, 72.6 billion were poultry. ${ }^{31}$ By far the most common mammal to be killed are pigs: 1.5 billion in $2013 .{ }^{32}$ If, attending to what it would mean for a pig to flourish as a pig, we agree that keeping them in monotonous and crowded indoor sheds with slatted floors for the entirety of their lives, and confining sows to crates in which they cannot even turn around, that means that Christians should avoid most pork. If we agree that taking dairy calves from their mothers even before they suckle for the first time, and forcing dairy cows to produce milk at levels that require the constant eating of food concentrates, being kept indoors without ever having the opportunity to graze grass, and being culled for beef after 3 or 4 lactations when their yield drops, fails to allow dairy cows to flourish adequately as creatures of God, then an increasing proportion of milk and other dairy products should be avoided by Christians. Beef cattle, and sheep are generally raised extensively, and generally fare better than chickens and pigs, but lambs are slaughtered at 2-6 months without having the opportunity to grow to maturity because of a consumer preference for younger flesh, and sheep and cows are still often subject to painful procedures such as castration and branding without anaesthetic. ${ }^{33}$

We have seen that harms inflicted on farmed animals in intensive modes of production must be judged incompatible with their flourishing as animal creatures of God. We can also look at this the other way around, and ask about what the flourishing of farmed animals might look like. One

${ }^{31}$ Figures from 2013 data downloaded from Food and Agriculture Organization of the United Nations Statistics Division, 'FAOSTAT3', (2013), URL: <http://faostat3.fao.org >. Fish are not counted in UN FAO reporting on food production, but my calculations for On Animals II suggests that 2.5-6.8 trillion fish are killed for food each year, representing numerically $98-99 \%$ of all animals killed for food (Clough, On Animals II, ch. 2.)

${ }^{32}$ Figures from Food and Agriculture Organization of the United Nations Statistics Division, 'FAOSTAT3'.

${ }^{33}$ Clough, On Animals II, ch. 2. 
fascinating study in Edinburgh in the 1980s took pigs from intensive systems, gave them access to a varied parkland environment, and watched the behaviour of the pigs over three years. They found the pigs built communal nests for shelter cooperatively, sited at a significant distance from feeding areas. They spent $51 \%$ of their time rooting in the earth. They exhibited complex social relationships, with particular friendships and association between siblings. Sows built nests to give birth at some distance from the communal nest, sometimes with log walls, and would not allow other pigs to enter. They were careful to keep areas of defecation separated from feeding and nesting areas, and imitated each other in marking trees. The life that these intensively reared pigs chose, given the opportunity, bore strong resemblances to their wild boar ancestors. ${ }^{34}$ This study indicates the kind of life that would obviously represent the flourishing of pigs, together with the vast distance between this and their lives confined in intensive systems. While access to acres of parkland might not be a viable alternative to current systems, it is entirely possible to design patterns of extensive rearing that would enable the pigs to engage in many of the species-specific behaviours the Edinburgh study documented. ${ }^{35}$ One academic friend who has worked on farmed animal welfare for a long time recently reported to me his surprise at visiting a farm where the heritage breed chickens flew up to roost in trees: we have forgotten what the lives of our farmed animals were like before we re-engineered their bodies and their environments for our convenience, and need help to reimagine the ways in which we could allow them to live lives in which they flourish in their particular modes of being and in that flourishing glorify their creator.

From the modest claim that Christians should be concerned about the flourishing of fellow animal creatures, through a summary survey of how modern intensive animal farming practices

${ }^{34}$ Bernard E. Rollin, Farm Animal Welfare: Social, Bioethical, and Research Issues (Ames, Iowa: Iowa State Press, 1995), pp. 74-5.

${ }^{35}$ Bernard Rollin surveyed the options available in 1995 in Rollin, Farm Animal Welfare: Social, Bioethical, and Research Issues, pp. 78-90. 
impact on animals, we have moved to the judgement that the vast majority of farmed animals are not raised in ways compatible with a Christian regard for them, and therefore that Christians should avoid supporting these unnecessarily cruel practices by not consuming products derived from them. This would have a rapid and direct effect on farmed animals: any reduction in demand for the animal products of intensive farming would mean fewer animals would be caught up in such production systems, and the market for higher welfare alternatives would expand, resulting in more animals having the opportunity to flourish within farmed settings.

One obvious counter-argument to this position is that the human interest in having access to cheap animal products outweighs the costs to the animals farmed intensively, and the higher prices for animal products that would be the consequence of ending intensive farming would reduce access to animal products, especially for those on low incomes. There are two reasons that this objection fails to be convincing. In the first place, it is clear that consuming animal products at current levels is not a benefit to human beings at all. Reducing global meat consumption would significantly advance human food and water security, reduce greenhouse gas emissions, reduce environmental pollution, reduce the risk of new human diseases, reduce the growth of antibiotic resistance, reduce the incidence of obesity and other dietary health problems, reduce the numbers of poor and migrant workers exploited in meat-packing plants and slaughterhouses, as well as reducing the numbers of animals subjected to the cruelty of intensive farming. ${ }^{36}$ The substantial benefit in improving the welfare of farmed animals therefore brings even greater human benefits. Second, while the particular impact of any change on those on low incomes should be a strong Christian concern, we do not reject regulation of other products on this ground. Safety standards for children's toys, minimum levels of pay for workers, and health and safety standards in factories all make products more expensive, but most agree that the higher prices that result represent the necessary costs of production, and should not be compromised in order to give those on low

\footnotetext{
${ }^{36}$ Clough, On Animals II, ch. 2.
} 
incomes better access to them. In a similar way, we should agree on appropriate standards for farmed animal welfare, and then make appropriate provision for a distribution of wealth that will allow appropriate access to these products, recognizing that current levels of production and consumption are unprecedented and unhealthy. Just as we should not put the lives of Bangladeshi garment workers at risk in order to permit the unsafe production of cheap clothes, so we should not continue our cruel treatment of farmed animals in order to mitigate unjust human income inequalities.

There are a range of other objections offered in relation to the argument that Christianity has strong implications for concern for animals. Some note that Jesus was not a vegetarian, so Christians should have no concern about eating animals. This is a good argument against an absolute Christian vegetarianism that says it is now and always been wrong to kill animals for food, but does not provide grounds to judge it permissible to subject farmed animals to a poor life in order to make products derived from them cheaper, which is what is at stake in my argument here. Others note that Jesus sent demons into the Gadarene swine (Matt. 8.28-33), but this story does not suggest that Jesus would have been unconcerned about the death of the pigs, and Michael Gilmour has even made the enticing suggestion recently that we could read this as a sacrificial action on the part of the pigs, cooperating with Jesus to ensure the demons were destroyed. ${ }^{37}$ Others argue that if God cares about gazelles, and this has relevance for ethics, it means we have an obligation to intervene to protect them from lions in the wild. This takes us back to the Christian recognition that we live in a fallen creation where we cannot bring peace between animal creatures, and where intervening to save prey from predators would result in the starvation of predators. We lament such conflicts, and look forward to the liberation of creation that will bring them to an end, but in the meantime should focus on the mistreatment of God's animal creatures that we are in a position to

${ }^{37}$ Michael J. Gilmour, Eden's Other Residents: The Bible and Animals (Eugene, Oregon: Cascade Books, 2014), p. 86. 
end: that vast harms we are directly inflicting on fellow animal creatures ourselves, through the cruelties of intensive farming..

In conversation I am often reminded of the importance of offering and receiving hospitality, and the complexity of negotiating family and wider social relationships in the context of avoiding particular animal products. I agree that these are morally weighty considerations, and that flexibility is important as guest and host, but believe that if we recognise the importance of the issue to Christian faith, we can negotiate these complexities in the context of our relationships, and that this will become easier over time. We have deep habits and longstanding traditions involving the consumption of animal products, of course, and people often baulk at the prospect of having to reconsider them, but while intensively farmed meat, dairy, and eggs massively dominate the global market, it is possible to find small scale producers who farm animals that have been allowed to flourish as creatures of God, and it is also possible to relearn habits and remake traditional meals in ways that do not require animal products at all. Steps away from a diet involving products derived from intensively farmed animals can be slow and moderate: a meat-free meal, a meat-free day, a meat-free Lent, for example. Christian traditions of fasting and dietary traditions in monastic communities focussed around abstaining from meat, so attention to this element of our diet is by no means foreign to Christians. For some reason, the perfect seems to be the enemy of the better in this area of ethics, preventing small steps in the right direction. This is a logic we should resist: reducing the consumption of intensively farmed animal products will quickly reduce the numbers of farmed animals caught up in these systems, as well as having broader beneficial impacts on human food and water security, greenhouse gas emissions, environmental pollution, and human health.

\section{Conclusion}

I have argued that Christians have strong faith-based reasons to avoid consuming animal products derived from animals that have not been allowed to flourish as fellow creatures of God, and to 
avoid participating in systems that disallow such flourishing. I have also argued that modern intensive farming of animals, from which the vast majority of current animal products are derived, fails to allow animals to flourish as creatures of God. Taken together, these conclusions indicate that Christians have reason to avoid most meat, dairy, and eggs currently offered for sale, and to avoid participating in its production.

It is striking that in nineteenth century Great Britain, Christians were at the vanguard of campaigns to introduce legislation against animal cruelty, were active in establishing what became the RSPCA, and at the end of the century led campaigns against vivisection. ${ }^{38}$ There is recent precedent, therefore, for Christians recognizing that their faith has implications for the treatment of animals and acting in response, and perhaps it is a timely moment for Christians to reappropriate this as a faith issue, and recognise the implications for their own consumption, and for farming practice. ${ }^{39}$ An important part of this work will be engaging with farmers, and Christian farmers in particular, to discuss with them what might constitute the adequate flourishing of the animals under their care.

For most of us eating animals has been an ordinary thing, without any particular relationship to our faith or ethical norms derived from it. It is clear, however, that this is a historical anomaly. In her paper in this issue of the journal, Ellen Davis reminds us that for the Levitical community sacrifice and meat-eating were personal and public, rather than impersonal and private. ${ }^{40}$ That is, meat-eating in this community was extraordinary, rather than ordinary. This has been true much more generally: until recently, meat-eating was ordinary only for the very wealthy. I submit that we

${ }^{38}$ Clough, On Animals II, ch. 2.

${ }^{39} \mathrm{I}$ founded the CreatureKind organization (http://becreaturekind.org) in 2015 to make the case to churches in the UK and North America that farmed animal welfare should be a faith concern.

${ }^{40}$ Ellen F. Davis, 'Identity and Eating: A Christian Reading of Leviticus', Studies in Christian

Ethics 30.1 (2017). 
need to return to seeing eating animals as extraordinary, particularly in relation to the extraordinary demands modern agricultural production makes on farmed animals, which I have surveyed briefly in this paper. I appreciate that it is a big step to come to see what we have become accustomed to see as the ordinary act of eating animals as extraordinary, and to recognise that consuming the animal products of intensive farming may be in conflict with fundamental Christian beliefs about God's ways with creation. I submit, however, that careful consideration of Christian ethics in this area, which I have attempted in this article, requires nothing less.

\section{Bibliography}

Aerts, S., R. Boonen, V. Bruggeman, J. De Tavernier, and E. Decuypere, 'Culling of Day-Old Chicks: Opening the Debates of Moria?', in Ethical Futures: Bioscience and Food Horizons, K. Millar, P. Hobson West, and B. Nerlich (eds.), (Wageningen: Wageningen Academic Publishers, 2009), pp. 117-22.

Aquinas, Thomas, Summa Theologica, trans. Fathers of the English Dominican Province, (London: Blackfriars, 1963).

Aristotle, Politics, trans. Reeve, C. D. C. (Indianapolis: Hackett, 1998).

Augustine, Saint, The City of God, ed. R. V. G. Tasker, trans. John Healey (London: Dent \& Sons, 1945).

Barad, Judith A, Aquinas on the Nature and Treatment of Animals (San Francisco; London: International Scholars, 1995).

Barnum, Priscilla Heath (ed.), Dives and Pauper (Oxford: Early English Text Society/Oxford University Press, 1976).

Barth, Karl, Church Dogmatics, vol. III/4, ed. G. W. Bromiley and T. F. Torrance, trans. A. T. MacKay et al. (Edinburgh: T. \& T. Clark, 1961).

Bauckham, Richard, 'Jesus and the Wild Animals (Mark 1:13): A Christological Image for an Ecological Age', in Jesus of Nazareth: Lord and Christ (Essays on the Historical Jesus and New Testament Christology), Joel B. Green, and Max Turner (eds.), (Grand Rapids: Eerdmans, 1994), pp. 3-21.

Berkman, John, 'Towards a Thomistic Theology of Animality', in Creaturely Theology: On God, Humans and Other Animals, Celia Deane-Drummond, and David Clough (eds.), (London: SCM, 2009), pp. 21-40.

Carson, Rachel, Silent Spring (Boston: Houghton Mifflin, 1961).

Clough, David, On Animals: Vol. I. Systematic Theology (London: T \& T Clark/Continuum, 2012). , On Animals: Vol. II. Theological Ethics (London: T \& T Clark/Bloomsbury, forthcoming 2017).

Davis, Ellen F., 'Identity and Eating: A Christian Reading of Leviticus', Studies in Christian Ethics 30.1 (2017). 
Food and Agriculture Organization of the United Nations Statistics Division, 'FAOSTAT3', (2013), URL: $<$ http://faostat3.fao.org $>$.

Gilmour, Michael J., Eden's Other Residents: The Bible and Animals (Eugene, Oregon: Cascade Books, 2014).

Godley, A, and B Williams, Democratizing Luxury and the Contentious "Invention of the Technological Chicken” in Britain, Business History Review (Reading, UK: Centre for Institutional Performance, University of Reading, 2009).

Jung, L. Shannon, Food for Life: The Spirituality and Ethics of Eating (Minneapolis: Fortress Press, 2004).

Linzey, Andrew, Animal Theology (London: SCM Press, 1994).

Luther, Martin, Lectures on Genesis, Chapters 1-5, Luther's Works, vol. I, ed. Jaroslav Pelikan (Saint Louis: Concordia, 1958).

- Luther's Works, eds. Helmut T. Lehmann, and Jaroslav Pelikan (Philadelphia: Muhlenberg Press, 1958).

McKenna, Maryn, 'By 2020, Male Chicks May Avoid Death By Grinder', National Geographic, 13th June, 2016, URL: <http://www.nationalgeographic.com/people-and-culture/food/theplate/2016/06/by-2020--male-chicks-could-avoid-death-by-grinder/>.

Muers, Rachel, and David Grumett (eds.), Eating and Believing: Interdisciplinary Perspectives on Vegetarianism and Theology (London: T \& T Clark, 2008).

Northcott, Michael S., The Environment and Christian Ethics (Cambridge: Cambridge University Press, 1996).

Pope Francis, Laudato Si: On Care for Our Common Home (Vatican City State: Vatican Press, 2015).

Pope Paul VI, Paenitemini: On Fast and Abstinence (Vatican City State: Vatican Press, 1966).

Regan, Tom, The Case for Animal Rights (Berkeley: University of California Press, 2nd ed. 2004).

Rollin, Bernard E., Farm Animal Welfare: Social, Bioethical, and Research Issues (Ames, Iowa: Iowa State Press, 1995).

Sider, Ronald J., Rich Christians in an Age of Hunger: Twentieth Anniversary Edition (London: Hodder \& Stoughton, 1997).

Sideris, Lisa H., 'The Secular and Religious Sources of Rachel Carson's Sense of Wonder', in Rachel Carson: Legacy and Challenge, Lisa H. Sideris, and Kathleen Dean Moore (eds.), (New York: SUNY Press, 2008), pp. 232-50.

Singer, Peter, 'All Animals Are Equal', Philosophical Exchange Vol. 1 (1974), 103-16.

$\longrightarrow$, Animal Liberation (London: Pimlico, 2nd ed. 1995).

Stuart, Tristram, The Bloodless Revolution: A Cultural History of Vegetarianism From 1600 to Modern Times (New York; London: W. W. Norton and Co., 2006).

Waddell, Helen, Beasts and Saints (London: Darton, Longman \& Todd, 1995).

Webb, Stephen H., Good Eating, The Christian Practice of Everyday Life, vol. The Christian practice of everyday life (Grand Rapids, MI: Brazos Press, 2001).

Wirzba, Norman, Food and Faith: A Theology of Eating (Cambridge: Cambridge University Press, 2011). 